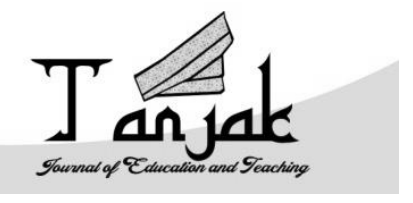

Tanjak: Journal of Education and Teaching

ISSN 2716-4098 (P) 2720-8966 (O)

Volume 2 Nomor 1, 2021

\title{
KEPUASAN KERJA GURU BERDASARKAN STATUS KEPEGAWAIAN DAN JENIS KELAMIN
}

\author{
Roby Maiva Putra ${ }^{1}$, Raja Arlizon ${ }^{2}$ \\ ${ }^{1}$ Sekolah Tinggi Agama Islam Negeri Sultan Abdurrahman, Bintan, Kepulauan Riau, 29151, Indonesia \\ ${ }^{2}$ Universitas Riau, Pekanbaru, Riau, 28293, Indonesia
}

DOI: https://doi.org/10.31629/jg.v2i1.244

\begin{abstract}
Abstrak
Proses pendidikan akan berjalan optimal apabila guru sebagai tenaga pendidik memiliki minat dan kepuasan yang tinggi terhadap profesinya tersebut. Penelitian ini bertujuan untuk: (1) melihat gambaran kepuasan kerja guru, (2) melihat perbedaan kepuasan kerja guru berdasarkan status PNS dan Non-PNS, dan (3) melihat perbedaan kepuasan kerja guru berdasarkan jenis kelamin. Penelitian ini menggunakan metode deskriptif kuantitatif. Penelitian ini dilaksanakan di Sekolah Menengah Kejuruan Negeri se-Kabupaten Kuantan Singingi, Provinsi Riau. Populasi dalam penelitian ini adalah guru yang terdaftar pada tahun pelajaran 2017/2018. Sampel diambil dengan menggunakan teknik proporsional random sampling dan didapatkan sebanyak 206 orang yang mana terdiri dari 85 orang berjenis kelamin laki-laki dan 121 orang perempuan atau 110 orang dengan status PNS dan 96 dengan status Non-PNS. Analisis data dilakukan dengan rumus persentase dan juga regresi sederhana. Temuan penelitian ini adalah: (1) kepuasan kerja guru sebagian besar berada pada kategori tinggi dengan persentase 83,49\%, (2) terdapat perbedaan yang signifikan antara kepuasan kerja guru yang berstatus PNS dan Non-PNS. Kepuasan kerja guru yang berstatus PNS lebih tinggi dibandingkan dengan guru yang berstatus Non PNS, (3) terdapat perbedaan yang signifikan antara kepuasan kerja guru laki-laki dan perempuan. kepuasan kerja guru yang berjenis kelamin perempuan lebih tinggi dibandingkan dengan guru yang berjenis kelamin laki-laki. Hasil penelitian ini dapat dijadikan masukan bagi Dinas Pendidikan dan kepala sekolah agar dapat memperbanyak program yang dapat meningkatkan kepuasan kerja guru.
\end{abstract}

Kata kunci: kepuasan kerja, status, jenis kelamin, guru

Tanjak: Jounal of Education and Teaching, Vol. 2, No. 1, 2021

http://ejournal.stainkepri.ac.id/index.php/tanjak 


\begin{abstract}
The education process will run optimally if teachers as educators have high interest and satisfaction with their profession. This study aims to: (1) see the description of teacher job satisfaction, (2) see differences in teacher job satisfaction based on civil servant and non-PNS status, and (3) see differences in teacher job satisfaction based on gender. This research uses descriptive quantitative method. This research was conducted at State Vocational High Schools throughout Kuantan Singingi Regency, Riau Province. The population in this study were teachers registered in the 2017/2018 school year. Samples were taken using proportional random sampling technique and obtained as many as 206 people, consisting of 85 men and 121 women or 110 people with civil servant status and 96 with nonPNS status. Data analysis was performed using a percentage formula and simple regression. The findings of this study are: (1) most of the teachers' job satisfaction is in the high category with a percentage of $83.49 \%$, (2) there is a significant difference between the job satisfaction of teachers who are PNS and Non-PNS. The job satisfaction of teachers with PNS status is higher than teachers with non PNS status, (3) there is a significant difference between the job satisfaction of male and female teachers. The job satisfaction of female teachers is higher than that of male teachers. The results of this study can be used as input for the Education Office and school principals in order to increase the number of programs that can increase teacher job satisfaction.
\end{abstract}

Keywords: job satisfaction, status, gender, teacher

\title{
Pendahuluan
}

Pendidikan memiliki peran yang sangat besar dalam upaya peningkatan kualitas sumber daya manusia. Melalui pendidikan, kepribadian manusia dapat dibina, serta dapat ditingkatkan harkat, martabat, dan nilai-nilai kemanusiaannya. Dengan pendidikan pula pola kehidupan manusia akan menjadi lebih baik dan terkontrol. Kualitas dan mutu pendidikan akan dipengaruhi oleh tenaga pendidik atau guru. Guru memiliki pengaruh yang sangat dominan dalam proses pencapaian tujuan serta mutu di satuan pendidikan. Guru juga bertindak sebagai fasilitator yang menyebabkan terciptanya kondisi kondusif bagi peserta didik dan disamping juga mempunyai tugas utama sebagai pengajar.

Guru bukanlah pekerjaan sambilan untuk menyalurkan hobi atau mengisi waktu luang, tetapi merupakan profesi yang harus dilaksanakan secara profesional dan terarah. Syamsuri (2010) berpendapat bahwa guru adalah komponen penting dalam dunia pendidikan yang kontribusinya sangat tinggi dalam upaya meningkatkan hasil belajar serta perkembangan peserta didik. Selain itu, guru juga merupakan tenaga profesional yang memiliki tanggung jawab yang besar dalam upaya pelaksanaan program belajar mengajar serta untuk mencapai hasil pembelajaran yang optimal.

Meskipun memiliki tanggungjawab yang sangat besar, ternyata masih banyak guru yang belum melaksanakan tugasnya tersebut dengan baik dan profesional. Permasalahan yang dimaksud misalnya konflik antara guru dengan kepala sekolah yang terjadi di salah satu sekolah di Kota Serang Banten pada tahun 2011 yang berimbas pada tidak berjalannya proses pembelajaran. Konflik ini terjadi akibat guru merasa kepala sekolah tidak transparan dalam masalah keuangan dan juga administrasi (https://edukasi.kompas.com).

Kemudian, Pada Tahun 2015 ada guru di Aceh yang terindikasi tidak mengajar selama berbulanbulan. Hal ini dikarenakan kurangnya motivasi guru dan juga rendahnya pengawasan yang dilakukan oleh kepala sekolah dan dinas terkait terhadap guru tersebut karena yang bersangkutan memiliki keluarga seorang pejabat (https://news.okezone.com).

Tanjak: Jounal of Education and Teaching, Vol. 2, No. 1, 2021 
Munculnya permasalahan di atas, kemungkinan besar dapat disebabkan oleh kurangnya kepuasan kerja guru terhadap profesinya tersebut sehingga berpengaruh pada rendahnya kedisiplinan dan motivasi kerjanya. Menurut Malayu (2007) kepuasan kerja merupakan salah satu bentuk emosi positif yang menyenangkan serta meningkatkan kecintaan individu terhadap pekerjaannya. Sikap ini akan memunculkan moral yang baik dalam bekerja, meningkatkan kedisiplinan serta prestasi kerja. Fei dan Han (2019) menyatakan bahwa kepuasan kerja guru berpengaruh terhadap berbagai aspek seperti hubungan sesama guru, iklim sekolah, komitmen, motivasi, kinerja, komitmen guru dan juga prestasi kerja guru. Kepuasan kerja juga akan berpengaruh pada minat seseorang terhadap suatu pekerjaan (Greenberg dan Baron, 2003).

Konteks "puas" dapat ditinjau dari tiga sisi, yaitu: (a) Setiap individu memiliki target tersendiri, apabila hasil atau imbalan yang diperoleh lebih dari yang diingikankan maka motivasinya akan tinggi dan individu akan berusaha atau bekerja keras. Capaian yang sesuai atau melebihi target akan menimbulkan kepuasan; (b) jika hasil yang diperoleh melebihi standar atau tuntutan. Hal ini akan membuat produktivitas individu meningkat; (c) jika individu mendapatkan hak sesuai dengan keinginan/permintaan/kontrak awal dan juga mendapatkan tambahan (hal-hal yang menyenangkan) maka individu itu akan konsisten dalam bekerja (Veitzhal, 2004). Kepuasan kerja ini juga terkait dengan beberapa hal yang berhubungan dengan pembagian tugas, upah atau gaji, promosi jabatan, supervisi dari pimpinan, rekan kerja serta kondisi sosial kerja (Luthans, 2006).

\section{Metode Penelitian}

Penelitian ini dilaksanakan di Sekolah Menengah Kejuruan Negeri (SMK) Se-Kabupaten Kuantan Singingi yang dimulai di bulan juli sampai dengan bulan bulan oktober tahun 2017. Populasi penelitian ini adalah guru SMK Negeri yang berjumlah sebanyak 481 orang. Pengambilan sampel menggunakan teknik proportional random sampling sehingga didapat sampel sebanyak 206 orang guru yang terdiri dari 85 orang yang berjenis kelamin laki-laki dan 121 orang berjenis kelamin perempuan atau 110 orang berstatus PNS dan 96 orang berstatus Non PNS. Penelitian ini termasuk dalam penelitian deskriptif kuantitatif.

Pengumpulan data dilakukan dengan menggunakan angket/kuesioner tertutup yang telah dikembangkan oleh peneliti. Pengolahan data kepuasan kerja guru dilakukan dengan menggunakan rumus persentase, yaitu:

$$
\mathrm{P}=\frac{\mathrm{f}}{n} \times 100
$$

Keterangan :

$\mathrm{P}=$ Tingkat persentase jawaban

$\mathrm{f}=$ Frekuensi jawaban

$\mathrm{n}=$ Jumlah sampel

(Sudijono, 2012:43)

Selanjutnya, untuk melihat perbedaan kepuasan kerja guru berdasarkan status kepegawaian dan jenis kelamin digunakan rumus Uji-T yang mana pengujiannya dilakukan dengan menggunakan bantuan program SPSS versi 21.

\section{Tanjak: Jounal of Education and Teaching, Vol. 2, No. 1, 2021}




\section{Hasil dan Pembahasan}

\section{Kepuasan Kerja Guru}

Berdasarkan pengolahan data yang telah dilakukan, maka didapatkan gambaran kepuasan guru sebagai berikut.

Tabel 1. Deskripsi Frekuensi Kepuasan Kerja Guru

\begin{tabular}{|c|c|c|c|}
\hline Kategori & Rentang Interval & $\mathbf{F}$ & $\mathbf{\%}$ \\
\hline Sangat Tinggi & $\geq 161$ & 27 & 13,11 \\
\hline Tinggi & $121-160$ & 172 & 83,49 \\
\hline Sedang & $81-120$ & 7 & 3,40 \\
\hline Rendah & $41-80$ & 0 & 0 \\
\hline Sangat Rendah & $\leq 40$ & 0 & 0 \\
\hline \multicolumn{2}{|c|}{ Jumlah } & $\mathbf{2 0 6}$ & $\mathbf{1 0 0}$ \\
\hline
\end{tabular}

Berdasarkan Tabel 3 di atas, maka dapat disimpulkan bahwa tingkat kepuasan kerja guru sebagian besar berada pada kategori tinggi yaitu sebanyak 172 orang atau 83,49\%. Kepuasan kerja pada dasarnya bersifat individual dengan kata lain memiliki tingkat yang berbeda-beda pada setiap individu sesuai dengan sistem nilai yang dimiliki. Semakin banyak aspek-aspek pekerjaan yang sesuai dengan diri individu, maka tingkat kepuasan kerja yang dimilikinya akan semakin tinggi terhadap pekerjaan tersebut. Menurut Veithzal (2004) kepuasan kerja merupakan perasaan yang muncul dari rasa terpenuhinya harapan atau keinginan individu.

Kepuasan kerja yang tinggi ini diharapkan dapat berdampak positif terhadap berbagai aspek terkait dengan tugas masing-masing guru. Cecilia (2008) mengatakan bahwa kepuasan kerja akan memberikan pengaruh yang signifikan terhadap kinerja serta sikap individu terhadap pimpinan, rekan/rekan ataupun lingkungan kerjanya. Hal ini berarti bahwa semakin puas individu terhadap pekerjaannya, maka akan semakin baik pula proses yang akan dilakukannya dalam pelaksanaan beban kerjanya. Sebaliknya, semakin rendah tingkat kepuasan individu, maka akan semakin rendah pula kinerja yang ditunjukkannya.

\section{Kepuasan Kerja Guru Berdasarkan Status Kepegawaian}

Untuk mengetahui tingkat kepuasan kerja guru berdasarkan jenis kelamin laki-laki dan perempuan dapat di lihat pada tabel di bawah ini.

Tabel 2. Gambaran kepuasan kerja guru berdasarkan status kepegawaian

\begin{tabular}{|c|c|c|c|c|c|}
\hline \multirow{2}{*}{ Kategori } & \multirow{2}{*}{ Rentang Skor } & \multicolumn{2}{|c|}{ PNS } & \multicolumn{2}{c|}{ Non PNS } \\
\cline { 3 - 6 } & & $\mathbf{F}$ & $\mathbf{0}$ & $\mathbf{F}$ & $\mathbf{0}$ \\
\hline Sangat Tinggi & $\geq 161$ & 26 & 23,6 & 1 & 1,04 \\
\hline Tinggi & $121-160$ & 84 & 76,4 & 90 & 93,75 \\
\hline sedang & $81-120$ & 0 & 0 & 5 & 5,21 \\
\hline Rendah & $41-80$ & 0 & 0 & 0 & 0 \\
\hline Sangat Rendah & $\leq 40$ & 0 & 0 & 0 & 0 \\
\hline \multicolumn{2}{|c|}{ Jumlah } & 110 & 100 & 96 & 100 \\
\hline
\end{tabular}

Berdasarkan hasil analisis data pada tabel di atas, maka dapat dilihat bahwa kepuasan kerja guru PNS berada pada kategori sangat sebesar 23,6\% dan tinggi sebesar 76,4\% sedangkan kepuasan kerja guru

Tanjak: Jounal of Education and Teaching, Vol. 2, No. 1, 2021 
Non PNS yang berada pada kategori tinggi sebesar 1,04\%, kategori tinggi 93, dan kategori sedang sebesar $5,21 \%$. Untuk melihat perbedaan kepuasan kerja guru berdasarkan status PNS dan Non-PNS dapat dilihat pada tabel berikut.

Tabel 3. Perbedaan kepuasan kerja guru PNS dan Non-PNS

\begin{tabular}{|c|c|c|c|c|c|c|c|c|}
\hline & \multicolumn{2}{|c|}{ Uji Levene's } & \multicolumn{6}{|c|}{ T-test } \\
\hline & \multirow[t]{2}{*}{$\mathrm{F}$} & \multirow[t]{2}{*}{ Sig. } & \multirow[t]{2}{*}{$\mathrm{t}$} & \multirow[t]{2}{*}{ Df } & \multirow[t]{2}{*}{$\begin{array}{l}\text { Sig. (2- } \\
\text { tailed) }\end{array}$} & \multirow[t]{2}{*}{$\begin{array}{l}\text { Std. Error } \\
\text { Difference }\end{array}$} & \multicolumn{2}{|c|}{$\begin{array}{c}95 \% \text { Confidence Interval } \\
\text { of the Difference }\end{array}$} \\
\hline & & & & & & & Lower & Upper \\
\hline $\begin{array}{c}\text { Kepuasan kerja } \\
\text { berdasarkan status } \\
\text { kepegawaian }\end{array}$ & ,870 &, 352 & 7,809 & 204 &, 000 & 1,55812 & 9,09515 & 15,23932 \\
\hline
\end{tabular}

Berdasarkan hasil analisis data diperoleh P-value sebesar 0.000 dan lebih kecil dari 0,05. Hal ini memiliki arti bahwa terdapat perbedaan yang signifikan antara kepuasan kerja guru PNS dan Non-PNS. Berdasarkan persentasenya, guru dengan status PNS memiliki kepuasan kerja yang lebih tinggi daripada guru yang berstatus Non PNS. Hal ini kemungkinan besar didasari oleh perbedaan upah atau gaji yang diterima. Pegawai tentu menginginkan gaji atau upah yang dianggapnya adil sesuai dengan beban kerja yang mereka terima. Ketika beban kerja sama tetapi jumlah upah yang diterima berbeda, maka kepuasannya juga akan berbeda-beda (Robbins, 2015). Kemudian, Mohamadpour, dkk (2016) menemukan bahwa kepuasan kerja berhubungan dengan kesejahteraan kerja yang diterima seseorang seperti jaminan sosial dan juga keterlibatan secara sosial.

Selain perbedaan dari segi gaji, guru yang berstatus Non PNS biasanya juga mendapatkan perlakukan yang berbeda oleh guru yang PNS padahal dalam profesionalitas kerja seharusnya tidak boleh ada yang membeda-bedakan. Padahal faktor dukungan teman ini merupakan salah satu indikator yang akan berpengaruh pada motivasi seseorang (Nalim, 2015). Selanjutnya, Auliani dan Wulanyani (2017) juga mengatakan bahwa ada sembilan faktor penting yang sangat berdampak pada kepuasan kerja seseorang yang diantaranya adalah faktor kondisi fisik tempat kerja.

Guru Non PNS biasanya juga kurang memiliki kesempatan untuk mendapatkan promosi jabatan baik karena aturan pemerintah ataupun kebijakan pimpinan di internal sekolah. Hal ini secara tidak langsung tentu akan berpengaruh pada ketidakepuasan kerja guru Non PNS. Ini sesuai dengan pendapat Ramaseshan, dkk (2006) bahwa ketidakpuasan kerja muncul dari rasa keterasingan yang diterima seseorang dari lingkungan pekerjaannya.

\section{Kepuasan Kerja Guru Berdasarkan Jenis Kelamin}

Untuk deskripsi hasil kepuasan kerja guru berdasarkan jenis kelamin, dapat dilihat pada tabel di bawah ini.

Tanjak: Jounal of Education and Teaching, Vol. 2, No. 1, 2021 
Tabel 4. Deskripsi Frekuensi Kepuasan Kerja Guru Berdasarkan Jenis Kelamin

\begin{tabular}{|c|c|c|c|c|c|}
\hline \multirow{2}{*}{ Kategori } & \multirow{2}{*}{ Rentang Skor } & \multicolumn{2}{|c|}{ Laki-laki } & \multicolumn{2}{|c|}{ Perempuan } \\
\cline { 3 - 6 } & & $\mathbf{F}$ & $\mathbf{\%}$ & $\mathbf{F}$ & $\mathbf{\%}$ \\
\hline Sangat Tinggi & $\geq 161$ & 5 & 5,89 & 22 & 18,18 \\
\hline Tinggi & $121-160$ & 76 & 89,41 & 98 & 80,99 \\
\hline Sedang & $81-120$ & 4 & 4,70 & 1 & 0,83 \\
\hline Rendah & $41-80$ & 0 & 0 & 0 & 0 \\
\hline Sangat Rendah & $\leq 40$ & 0 & 0 & 0 & 0 \\
\hline \multicolumn{2}{|r|}{ Jumlah } & 85 & 100 & 121 & 100 \\
\hline
\end{tabular}

Berdasarkan hasil analisis data pada tabel di atas, maka dapat dilihat bahwa kepuasan kerja guru yang berjenis kelamin laki-laki dengan kategori sangat tinggi yaitu sebesar 5,89\%, kategori tinggi sebesar $89,41 \%$, dan kategori sedang sebesar 4,70\%. Sedangkan tingkat kepuasan kerja guru yang berjenis kelamin perempuan yang berada pada kategori sangat tinggi sebesar 18,18\%, kategori tinggi sebesar $80,99 \%$, dan kategori sedang sebesar 0,83\%. Untuk melihat perbedaan kepuasan kerja guru berdasarkan jenis kelamin dapat dilihat pada tabel berikut.

Tabel 5. Perbedaan kepuasan kerja guru laki-laki dan perempuan di SMK Negeri se-Kabupaten Kuantan Singingi

\begin{tabular}{|c|c|c|c|c|c|c|c|c|c|}
\hline & \multicolumn{2}{|c|}{ Uji Levene's } & \multicolumn{7}{|c|}{ T-test } \\
\hline & \multirow[t]{2}{*}{$\mathrm{F}$} & \multirow[t]{2}{*}{ Sig. } & \multirow[t]{2}{*}{$\mathrm{t}$} & \multirow[t]{2}{*}{$\mathrm{df}$} & \multirow[t]{2}{*}{$\begin{array}{l}\text { Sig. (2- } \\
\text { tailed) }\end{array}$} & \multirow[t]{2}{*}{$\begin{array}{c}\text { Mean } \\
\text { Differen } \\
\text { ce }\end{array}$} & \multirow{2}{*}{$\begin{array}{c}\text { Std. } \\
\text { Error } \\
\text { Differen } \\
\text { ce }\end{array}$} & \multicolumn{2}{|c|}{$\begin{array}{c}95 \% \text { Confidence } \\
\text { Interval of the } \\
\text { Difference }\end{array}$} \\
\hline & & & & & & & & Lower & Upper \\
\hline $\begin{array}{c}\text { kepuasan kerja } \\
\text { berdasarkan jenis } \\
\text { kelamin }\end{array}$ & ,832 & ,363 & $-5,027$ & 204 & ,000 & $-8,53223$ & 1,69732 & $-11,878$ & $-5,1856$ \\
\hline
\end{tabular}

Berdasarkan hasil analisis data didadaptkan P-value sebesar 0.000 yang mana lebih kecil dari 0,05 hal ini berarti bahwa terdapat perbedaan yang signifikan antara kepuasan kerja guru laki-laki dan perempuan. Dari hasil analisis data, guru perempuan memiliki tingkat kepuasan kerja yang lebih tinggi jika dibandingkan dengan guru yang berjenis kelamin laki-laki.

Temuan di atas sejalan dengan penelitian Anwar (2001) yang menyatakan bahwa kepuasan kerja dipengaruhi oleh beberapa hal yang salah satunya adalah jenis kelamin. Lebih lanjut, Justrina (2011) juga menyatakan bahwa kepuasan kerja karyawan yang berjenis kelamin perempuan lebih tinggi daripada lakilaki. Kemudian penelitian Ester, dkk (2017) juga menemukan kepuasan kerja guru perempuan lebih tinggi jika dibandingkan dengan guru laki-laki sehingga mereka merekomendasikan kepada dinas pendidikan agar lebih banyak merekrut guru perempuan daripada laki-laki. Hal ini kemungkinan disebabkan oleh berbagai hal yang diantaranya perempuan yang sifatnya lebih cenderung penurut, loyal serta lebih fokus terhadap pekerjaannya.

Tanjak: Jounal of Education and Teaching, Vol. 2, No. 1, 2021 


\section{Kesimpulan}

Berdasarkan uraian hasil penelitian yang sudah dipaparkan sebelumnya, maka dapat simpulkan sebagai berikut.

1. Kepuasan kerja guru sebagian besar berada pada kategori tinggi.

2. Terdapat perbedaan yang signifikan antara kepuasan kerja guru yang berstatus PNS dan Non-PNS. Kepuasan kerja guru yang berstatus PNS lebih tinggi dibandingkan dengan guru yang berstatus Non PNS.

3. Terdapat perbedaan yang signifikan antara kepuasan kerja guru laki-laki dengan guru perempuan. Kepuasan kerja guru yang berjenis kelamin perempuan lebih tinggi jika dibandingkan dengan guru yang berjenis kelamin laki-laki.

\section{Ucapan Terimakasih}

Terima kasih yang sebesar-besarnya kami ucapkan kepada semua pihak yang telah berpartisipasi dalam penelitian ini, khususnya kepala sekolah dan guru-guru sekolah menengah kejuruan negeri di Kabupaten Kuantan Singingi Provinsi Riau. Semoga hasil penelitian ini dapat memberikan manfaat serta dapat dijadikan dasar bagi para pemangku kebijakan, baik ditingkat provinsi/daerah dan juga pihak pimpinan sekolah untuk meningkatkan kepuasan kerja guru.

\section{Referensi}

Anwar, P. M. 2001. Manajemen Sumber Daya Manusia Perusahaan. Bandung: Remaja Rosdakarya.

Cecilia, E. 2008. Pengaruh Kepuasan Kerja terhadap Kinerja Individual dengan Self Esteem dan Self Efficacy sebagai Variabel Intervening. Jurnal Bisnis dan Akutansi, Vol. 10, No.1.

Fei, E. L. E \& Han, C. G. K. 2019. The Influence Of School Climate, Teachers' Commitment, Teachers' Motivation On Teachers' Work Performance Through Teachers' Job Satisfaction. International Journal Of Advanced Research In Education And Society, Vol. 1, No. 3, 23-35.

Greenberg, G \& Baron, R.A. 2003. Behavior in Organization: Understanding and Managing the Human Side of Work. Boston: Allyn and Bacon.

Https://edukasi.kompas.com. 2011. Guru dan Kepsek Konflik, Siswa Jadi Korban. (Penulis: Joewono, B. N. Diakses Tanggal 15 Juli 2017,

Https://news.okezone.com. 2015. Disiplin Rendah, Guru Tidak Mengajar Berbulan-bulan. (Penulis: Anonim). Diakses Tanggal 15 Juli 2017,

Justrina, S. 2011. Analisis Kepuasan Kerja Karyawan Berdasarkan Perbedaan Karakteristik Jenis Kelamin. Jurnal Murni Sadar, Vol.1 No.2.

Luthans, F. (2006). Perilaku organisasi. Yogyakarta: Penerbit ANDI.

Mohamadpour, S., Fathi, S., \& Moktarpour, M. 2016. Studying the Factors Affecting Job Satisfaction among the Students of Islamic Azad University (Case of Study: Science and Research Branch, Tehran). International Journal of Social Sciences (IJSS), Vol.6, No.4, 63.74.

Tanjak: Jounal of Education and Teaching, Vol. 2, No. 1, 2021

http://ejournal.stainkepri.ac.id/index.php/tanjak 
Nalim. 2015. Analisis Faktor Yang Mempengaruhi Motivasi Belajar Mahasiswa Yang Kuliah Sambil Bekerja, Jurnal Ilmiah Kependidikan Khasanah Pendidikan, Vol 08, No 2 (1-15).

Ramaseshan, B., Leslie, S.C.Y., dan Jae H. P. 2006. Power, Satisfaction and Relationship Commitment in Chinese Store Tenant Relationship and Their Impact on Performance. Journal of Retailing; Vol. 82 No 1, 63-70.

Robbins, S. (2015). Psikologi organisasi. Jakarta: Salemba Empat.

Sudijono, A. 2012. Pengantar Statistik Pendidikan. Jakarta: Raja Grafindo Persada.

Syamsuri, I. 2010. Peningkatan Kompetensi Guru untuk Meningkatkan Minat Siswa pada Bidang MIPA. Makalah disampaikan dalam Lokakarya MIPA 2010, The Indonesian Network of Higher Educations of Mathematics and Nanutal Sciences, tanggal 26-27 Juli 2010, di IPB, Bogor.

Veithzal, R. 2004. Manajemen Sumber Daya Manusia Untuk Perusabaan. Jakarta: Raja Grafindo Persada. 